\title{
Closed loop control of DC-DC converters using PID and FOPID controllers
}

\author{
Aseem K, Selva Kumar S \\ Department of Electrical and Electronics Engineering, Amrita School of Engineering, Amrita Vishwa Vidyapeetham, \\ India.
}

\begin{tabular}{lll} 
Article Info & ABSTRACT \\
\cline { 3 - 3 } Article history: & $\begin{array}{l}\text { Fractional order controllers are nowadays used in various power electronic } \\
\text { converters as it is giving superior control performance compared with } \\
\text { conventional PID controllers. This paper presents the closed loop control of } \\
\text { Received Dec 11, } 2019 \\
\text { Revised Feb 4, 2020 } \\
\text { Accepted Apr 26, 2020 }\end{array}$ & $\begin{array}{l}\text { (FOPID) controllers. The closed loop control of the basic converters such as } \\
\text { buck, boost, buck-boost converters and dual input single output DC-DC } \\
\text { converters were designed, modeled and analyzed using conventional PID }\end{array}$ \\
Keywords: & $\begin{array}{l}\text { controller and FOPID controllers. The performance of the controllers are } \\
\text { compared in terms of the different time domain specifications like overshoot, } \\
\text { rise time, settling time, etc. and simulated in MATLAB Simulink platform. }\end{array}$ \\
Boost type converter & $\begin{array}{l}\text { For all types of the DC-DC converters, FOPID controller gives far better } \\
\text { performance compared with conventional PID controllers. }\end{array}$ \\
Buck type converter & Buck-boost type converter &
\end{tabular}

Dual input-single output

converter

FOPID controller

PID controller

\section{Corresponding Author:}

Aseem K,

Department of Electrical and Electronics Engineering,

Amrita School of Engineering, Coimbatore,

Amrita Vishwa Vidyapeetham, India.

Email: azieee@gmail.com
This is an open access article under the $\underline{C C B Y-S A}$ license.

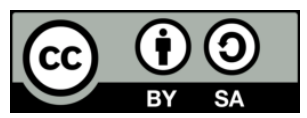

\section{INTRODUCTION}

Generally, DC-DC converters are the simple power electronic devices that switches one level of input voltage to another level of output voltage. Normally, DC-DC converter output voltage can be controlled using PWM switching with PID controllers in closed loop. DC-DC converters are mainly used in switched mode dc power supplies, DC motor drives, computer switched mode power supplies, office devices, control of appliances, communication equipment, aircrafts, regenerative braking of DC motors, etc. Many applications of the DC-DC converters are demanding the fast tracking of the reference voltages with minimum transients. As the power electronics converters are nonlinear, we require an adequate controller to meet these specifications. By using these conventional controller, the output voltage may contain large overshoots, high settling time, and the waveform obtained will not be smooth. Improvements in the reduction of the overshoots, settling time, rise time, etc. can be obtained by Fractional Order PID (FOPID) controllers. Buck and boost DC-DC converters are controlled by hybrid and optimal controllers in [1]. Here, the good performance can only be achieved with the consideration of nonlinear nature of the control problem. The load and line regulations are tested using adaptive fuzzy controller and performance evaluated in [2]. A fast response speed with respect to the reference and load voltage variation is achieved using model predictive voltage control [3]. A zero steady state error is achieved using a kalman filter based model predictive controller in step down dc-dc converter [4]. Closed loop control is carried out using exact feedback linearization technique to standard DC-DC buck converter in [5] .FOPID controllers have five tunable parameters in addition to the three gain parameters of the conventional PID controllers. Hence the flexibility 
of FOPID controllers are more than the conventional PID controllers. The design of Fractional Order PID controller can be made by finding the values of parameters $\mu$ (in derivative order) and $\lambda$ (in integrator order). This paper is organised in such a way that the section 2 explains the operation of various DC-DC converters under study. Section 3 describes the structure of conventional PID and FOPID controllers. Section 4 depicts the closed loop control and analysis of converters using conventional PID and FOPID controllers and the comparative analysis of performance of controllers. The conclusion is given in the section 5 followed by references.

\section{OPERATION OF DIFFERENT DC-DC CONVERTERS}

\subsection{Buck converter}

This converter is also called as step down converter which produces the average output lower than the input DC voltage. Figure1 shows the circuit diagram of buck converter. During the period when the switch is closed $\left(t_{o n}\right)$, the diode becomes reverse biased. The input voltage is delivered to the load and inductor. The voltage across the inductor, $V_{L}=V_{d}-V_{0}$. During the period when the switch is open $\left(t_{o f f}\right)$, the diode becomes forward biased and the input voltage cannot be delivered to the load as well as to the inductor. The stored energy in inductor is transferred to the load i.e. $V_{L}=-V_{O}$. The equivalent circuit diagrams are shown in Figure 2.

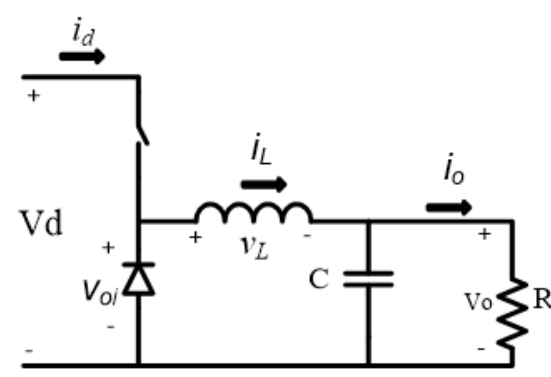

Figure 1. The buck converter

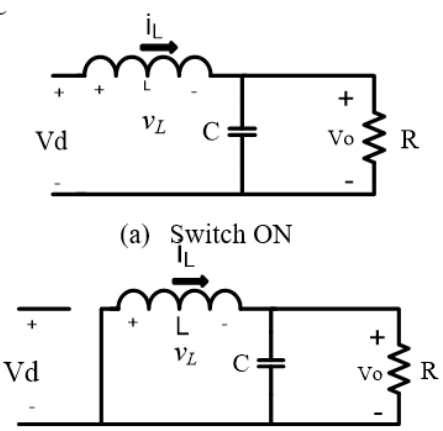

(b) Switch OFF

Figure 2. Equivalent circuit diagrams

Design equations of the buck converter are given below [6, 7].

The ratio between output voltages $V_{0}$ to the input voltage

$V_{d}$ is $\frac{V_{O}}{V_{d}}=D$

where $\mathrm{D}$ is the duty ratio

By assuming no power loss occurs in the converter, the current ratio is

$$
\frac{I_{O}}{I_{d}}=\frac{1}{D}
$$

the inductor current ripple,

$$
\Delta I_{L}=\frac{V_{0}}{L}(1-D) T_{s}
$$

the peak - peak output voltage ripple $\Delta V_{0}$ is given by,

$$
\Delta V_{O}=\frac{\Delta Q}{C}=\frac{T_{S}}{8 C} \frac{V_{O}}{L}(1-D) T_{s}
$$

\subsection{Boost converter}

This converter is a step up type converter which produces an output voltage higher than that of the input voltage. Figure 3 shows the circuit diagram of boost converter. During the interval when the switch 
is ON $\left(t_{o n}\right)$, diode is reverse biased and input is thus isolated from the load. When the switch is OFF $\left(t_{o f f}\right)$, the diode is forward biased, the output load receives energy from the input and inductor as well. The equivalent circuit are shown in Figure 4.

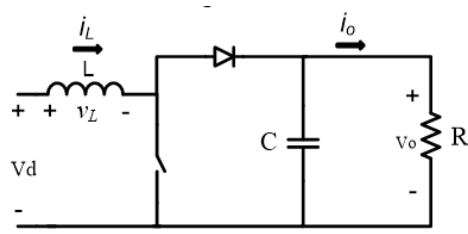

Figure 3. Boost converter

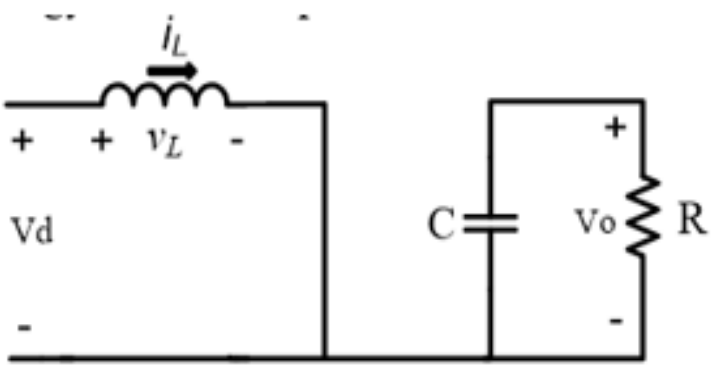

(a)

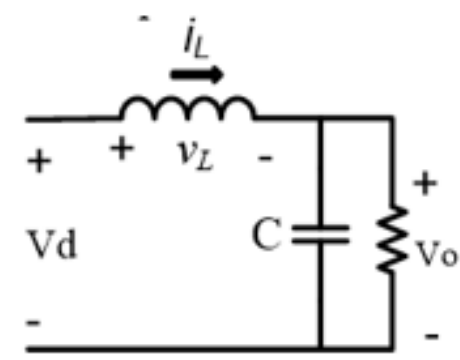

(b)

Figure 4. Equivalent circuit diagram, (a) switch on, (b) switch off

Design equations of the boost converter are given below [6, 7].

The ratio between the output voltage $V_{0}$ to the input voltage $V_{d}$ is

$$
\frac{V_{O}}{V_{d}}=\frac{1}{1-D}
$$

By assuming no power losses occures, the current ratio is

$$
\frac{I_{O}}{I_{d}}=1-D
$$

The Inductance,

$$
L=\frac{D V_{d}}{f_{s} \Delta I_{L}}
$$

Capacitance $C=\frac{D I_{0}}{f_{S} \Delta V_{0}}$

The peak - peak output voltage ripple is given by,

$$
\Delta V_{O}=\frac{\Delta Q}{C}=\frac{I_{0} D T_{S}}{C}
$$

\subsection{Buck-boost converter}

A buck boost type converter can be obtained by cascading the two basic converter i.e., Buck type converter and Boost type converter. The circuit diagram for the buck-boost type converter shown in the Figure 5. The higher/lower level of output voltage is obtained in the buck-boost converter depends upon the duty ratio, but it has $\mathrm{s}$ a negative polarity output voltage with respect to the common terminal of the input voltage. During the period when switch is ON, the load gets isolated from the input and inductor gets energy from the input voltage. During the period when switch is OFF, the output load is again 
isolated from the input and the stored energy of the inductor is transferred to the load. The equivalent circuit diagrams are shown in Figure 6.

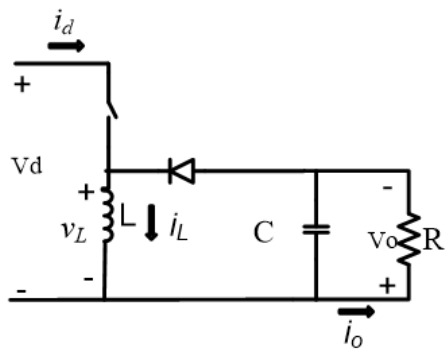

Figure 5. Buck-boost type converter

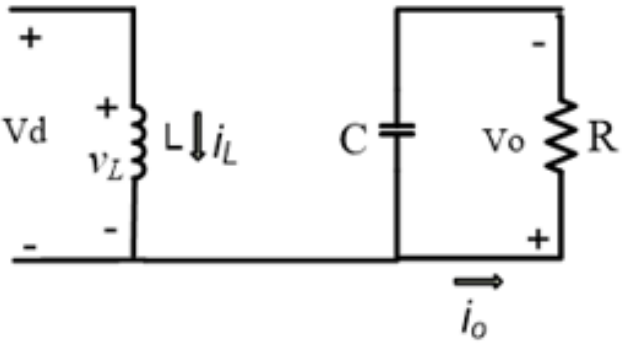

(a)

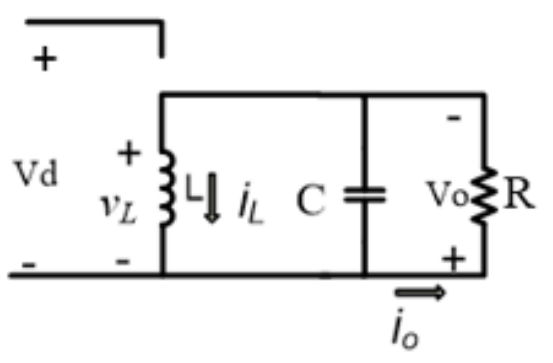

(b)

Figure 6. Equivalent circuit diagrams, (a) switch on, (b) switch off

Design equations of the buck-boost converter is given below [6, 7].

The ratio between the output voltage $V_{0}$ to the input voltage

$V_{d}$ is $\frac{V_{O}}{V_{d}}=\frac{D}{1-D}$

The Inductance,

$L=\frac{D V_{d}}{f_{s} \Delta I_{L}}$

Capacitance,

$C=\frac{D I_{0}}{f_{s} \Delta V_{0}}$

The peak to peak output ripple voltage,

$$
\Delta V_{O}=\frac{\Delta Q}{C}=\frac{V_{0} D T_{S}}{R C}
$$

\subsection{Dual input single output (DISO) converter}

The Dual input single output type DC-DC converters has a two voltage sources as input as shown in Figure 7. It combines the features of the buck type, boost type and buck boost type converters. There are four modes of operation based on the input voltage sources and ON and OFF conditions of the two switches $\mathrm{S}_{1}$ and $S_{2}$. The input voltage charges the inductor of the converter during the ON and OFF states of the two switches. When both switches are ON, the diodes are reverse biased and when both switches are OFF, the diodes are forward biased. 


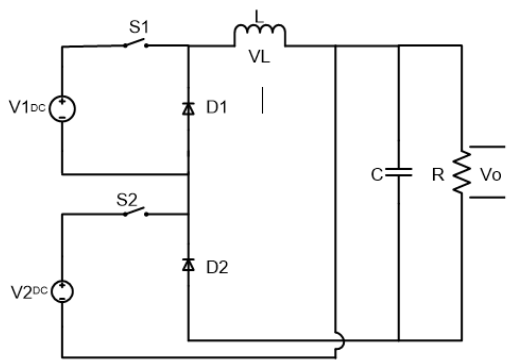

Figure 7 Dual input single output (DISO) converter

The input and the output voltage relationship based on the two duty cycles $D_{1}$ and $D_{2}$ are given by the equation

$$
V_{O}=\frac{D_{1}}{1-D_{1}} V_{1}+\frac{D_{2}}{1-D_{2}} V_{2}
$$

\section{CONVENTIONAL PID AND FOPID CONTROLLERS}

\subsection{Conventional PID controllers}

The PID controller tuner shown Figure 8(a) uses the formula

$$
G_{c}(s)=\frac{U(s)}{E(s)}=\left(K_{P}+\frac{K_{I}}{s}+K_{D} s\right)
$$

Where,

$K_{P}$ - Proportional control gain, $K_{I}$ - Integral gain, $K_{D}$ - Derivative gain

\subsection{Fractional order PID controllers}

The fractional order based PID controllers or $P I^{\lambda} D^{\mu}$ controllers consists of fractional integrator and fractional derivative that helps to improve the output of closed loop systems [9]. The transfer function of the fractional order PID controller shown in Figure 8 (b) is given below,

$$
G_{C}(s)=\frac{U(s)}{E(s)}=K_{P}+K_{I} s^{-\lambda}+K_{D} S^{\mu}
$$

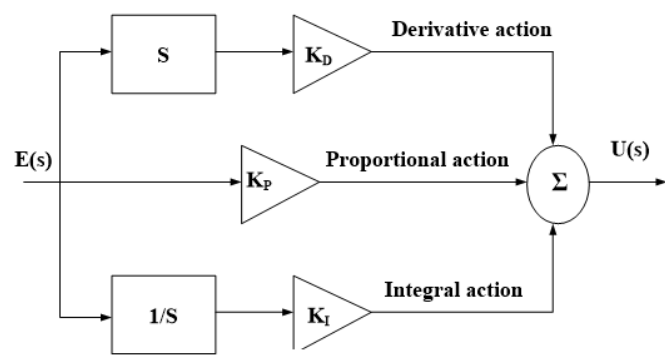

(a)

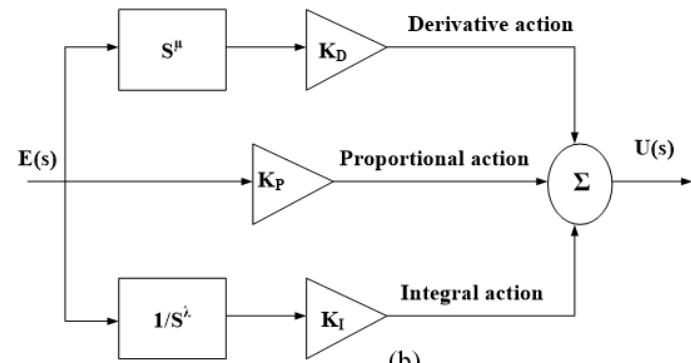

(b)

Figure 8 General block diagram of PID and FOPID controller

\section{CLOSED LOOP CONTROL OF DC-DC CONVERTERS USING PID AND FOPID CONTROLLERS}

In closed loop control of DC-DC converters, output voltage error corresponding to the variation in the input voltage is eventually gets corrected by the automatic feedback control. This leads to slow dynamic performance in regulating the output with respect to the changes in input voltage [10]. If the duty ratio could be adjusted such that to accommodate the change in the input, then the converter output would be regulated. 
Hence PID or FOPID controllers introduced with PWM techniques [11]. The general block diagram shown in Figure 9.

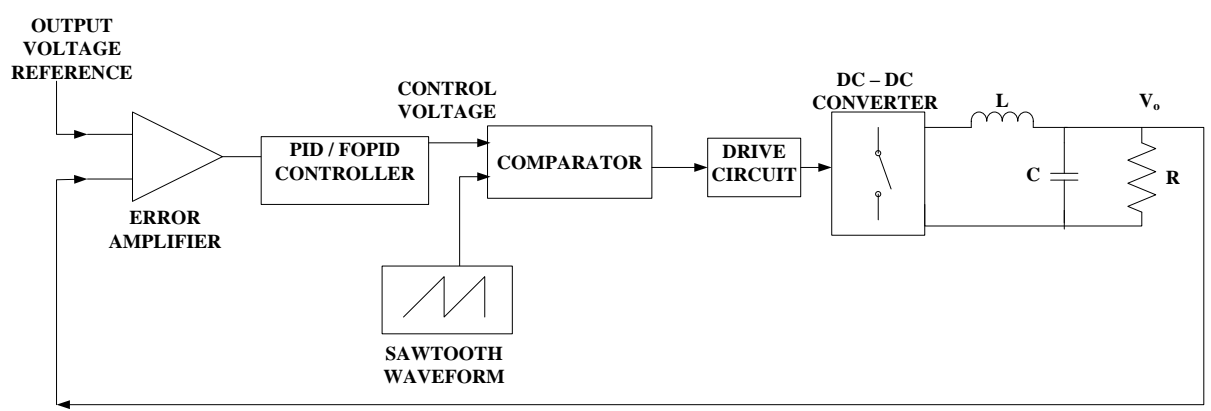

Figure 9. General block diagram of closed loop control of DC-DC converters

\subsection{Closed loop control of buck converter using PID and FOPID controllers}

The buck converter is designed using the equations 1-4 as given in section 2.1 and are shown in the Table 1. Design Values of PID controller are shown in the Table 2. The converter output voltage is regulated with lesser settling and rise time using FOPID controller compared with PID controller. The output voltage ripple is drastically reduced with FOPID controller. The overshoot is reduced considerably from a higher value to a negligible value with the use of FOPID controller. The under shoot and the slew rates are also improved with the used FOPID over PID controllers. The performance comparison of buck converter with conventional PID and FOPID are given in Table 3. The comparison of response of the converter under these two controllers are shown in Figure 10.

Table 1. Design parameters of the buck converter

\begin{tabular}{cc}
\hline Parameter & Value \\
\hline Input Voltage, $V_{D}$ & $24 \mathrm{~V}$ \\
Inductance, L & $0.1 \mathrm{H}$ \\
Capacitance, C & $47 \mu \mathrm{F}$ \\
Load Resistance, R & $25 \Omega$ \\
Switching frequency & $5000 \mathrm{~Hz}$ \\
Duty cycle, D & 0.4 \\
\hline
\end{tabular}

Table 2. Design Values of controllers

\begin{tabular}{cccccc}
\hline Controller & $K_{P}$ & $K_{I}$ & $K_{D}$ & $\lambda$ & $\mu$ \\
\hline FOPID & 0.702 & 0.6 & 0.45 & 0.885 & 1.2 \\
PID & 0.94 & 0.45 & 0.5847 & - & - \\
\hline
\end{tabular}

Table 3. The performance comparison of buck converter with conventional

\begin{tabular}{lllllllll}
\multicolumn{8}{c}{ PID and FOPID controllers } \\
\hline Controller & Vd & Vo & $\begin{array}{l}\text { Rise Time } \\
(\mathrm{ms})\end{array}$ & $\begin{array}{l}\text { Slew rate } \\
(\mathrm{mv} / \mathrm{s})\end{array}$ & $\begin{array}{l}\text { Ripple } \\
(\mathrm{V})\end{array}$ & $\begin{array}{l}\text { Overshoot } \\
\%\end{array}$ & $\begin{array}{l}\text { Under- } \\
\text { Shoot } \%\end{array}$ & $\begin{array}{c}\text { Settling Time } \\
\text { (V) }\end{array}$ \\
\hline PID & 24 & 9.933 & 92.687 & 85.735 & 0.02 & 15.698 & 2.000 & $19.98 \mathrm{~ms}$ \\
FOPID & 24 & 9.99 & 40.614 & 105.223 & 0 & 0.505 & 2.060 & $0.003 \mathrm{~ms}$ \\
\hline
\end{tabular}

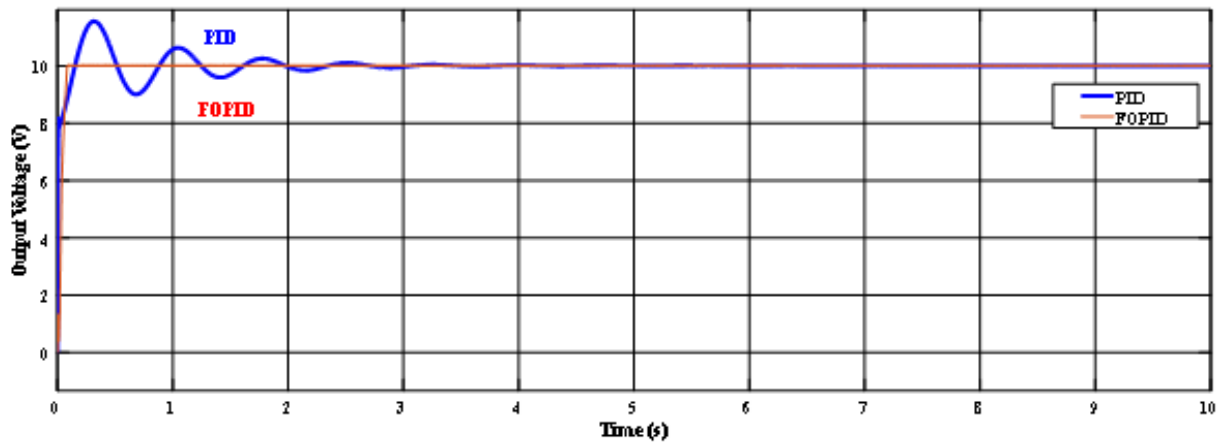

Figure 10 Comparison of output voltage of buck converters using PID and FOPID controllers 


\subsection{Closed loop control of boost converter using PID and FOPID controllers}

The boost converter is designed using the equations 5-9 as given in section 2.2 and are shown in Table 5. Design values of PID and FOPID controllers are shown in the Table 6 . The converter output voltage is regulated at desired voltage level with lesser settling and rise time using FOPID controller compared with PID controller. The output voltage ripple drastically reduced with FOPID controller as in the case of buck converter. The overshoot is reduced considerably with the use of FOPID controller. The undershoot and the slew rates are improved with the FOPID controllers over PID controllers.

Table 4. The performance comparison of boost converter with conventional PID and FOPID controllers

\begin{tabular}{lllllllll}
\hline Controller & $\begin{array}{l}\text { Vd } \\
(\mathrm{V})\end{array}$ & $\begin{array}{l}\text { Vo } \\
(\mathrm{V})\end{array}$ & $\begin{array}{l}\text { Rise Time } \\
(\mu \mathrm{s})\end{array}$ & $\begin{array}{l}\text { Slew rate } \\
(\mathrm{mv} / \mathrm{ms})\end{array}$ & $\begin{array}{l}\text { Ripple } \\
(\mathrm{V})\end{array}$ & $\begin{array}{l}\text { Overshoot } \\
\%\end{array}$ & $\begin{array}{l}\text { Under- } \\
\text { Shoot } \%\end{array}$ & $\begin{array}{l}\text { Settling } \\
\text { Time }\end{array}$ \\
\hline PID & 5 & 11.61 & 432.533 & 21.839 & 0.5 & 27.564 & -1.047 & $19.919 \mathrm{~ms}$ \\
FOPID & 5 & 11.99 & 606.711 & 15.805 & 0.001 & 1.531 & 1.032 & $.434 \mathrm{~ms}$ \\
\hline
\end{tabular}

The performance comparison of boost converter with conventional PID and FOPID are given in Table 4. The comparison of response of the boost converter under PID and FOPID controllers are shown in Figure 11.

Table 5. Design parameters of the boost converter

\begin{tabular}{ll}
\hline Parameter & Value \\
\hline Input Voltage $V_{D}$ & $5 \mathrm{~V}$ \\
Inductance L & $150 \mu \mathrm{H}$ \\
Capacitance C & $200 \mu \mathrm{F}$ \\
Load Resistance R & $30 \Omega$ \\
Switching frequency & $5000 \mathrm{~Hz}$ \\
Duty cycle & 0.6 \\
\hline
\end{tabular}

Table 6. Design values of controllers

\begin{tabular}{llccll}
\hline Controller & $K_{P}$ & $K_{I}$ & $K_{D}$ & $\lambda$ & $\mu$ \\
\hline FOPID & 1.536 & 95 & 0.0004 & 0.9999 & 0.5255 \\
PID & 1.0265 & 3.56 & 0.0003 & - & - \\
\hline
\end{tabular}

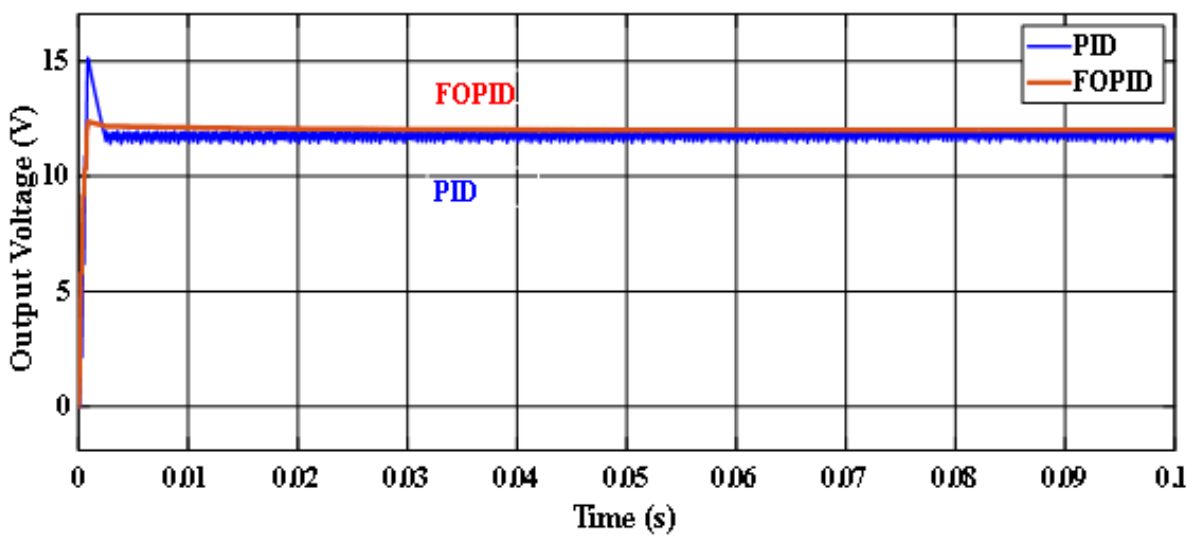

Figure 11. Comparison of output voltage of boost converters using PID and FOPID controllers

\subsection{Closed loop control of Buck-Boost type converter using conventional PID and FOPID controllers}

The designed values for the parameters of the buck-boost converter are shown in Table. 7, which is evaluated from the equations 10-13.The values of various gain parameters used in the controllers are listed in the Table. 8. The performance comparison of buck-boost converter with conventional PID and FOPID are given in Table. 9. The transient performance of the FOPID controller is better than that of PID controllers. The overshoot and settling time are improved well with the use of FOPID controllers. The comparison of response of the buck-boost converter under PID and FOPID controllers are shown in Figure 12. 
Table 7. Design parameters of the buck-boost converter

\begin{tabular}{cc}
\hline Parameter & Value \\
\hline Input Voltage, $V_{D}$ & $15 \mathrm{~V}$ \\
Inductance, $\mathrm{L}$ & $150 \mu \mathrm{H}$ \\
Capacitance, C & $250 \mu \mathrm{F}$ \\
Load Resistance, R & $50 \Omega$ \\
Switching frequency & $5000 \mathrm{~Hz}$ \\
Duty cycle & 0.6 \\
\hline
\end{tabular}

Table 8. Design values of controllers

\begin{tabular}{cccccc}
\hline Controller & $K_{P}$ & $K_{I}$ & $K_{D}$ & $\lambda$ & $\mu$ \\
\hline FOPID & 0.1844 & 77.4486 & 0.2118 & 1.88 & 0.65 \\
PID & 0.8758 & 84.013 & $7 \mathrm{e}-4$ & - & - \\
\hline
\end{tabular}

Table 9. The performance comparison of buck-boost converter with conventional PID and FOPID controllers

\begin{tabular}{lllllllll}
\hline Controller & $\begin{array}{l}\text { Vd } \\
(\mathrm{V})\end{array}$ & $\begin{array}{l}\text { Vo } \\
(\mathrm{V})\end{array}$ & $\begin{array}{l}\text { Rise Time } \\
(\mathrm{ms})\end{array}$ & $\begin{array}{l}\text { Slew rate } \\
(\mathrm{mv} / \mathrm{ms})\end{array}$ & $\begin{array}{l}\text { Ripple } \\
(\mathrm{V})\end{array}$ & $\begin{array}{l}\text { Overshoot } \\
\%\end{array}$ & $\begin{array}{l}\text { Under- } \\
\text { Shoot } \\
\%\end{array}$ & $\begin{array}{l}\text { Settling } \\
\text { Time } \\
\mathrm{ms}\end{array}$ \\
\hline PID & 15 & 55.95 & 7.212 & -8.279 & 0.8 & 3.761 & 1.314 & 12.56 \\
FOPID & 15 & 57.16 & 6.232 & -22.283 & 0.05 & 2.460 & 2.577 & 8.905 \\
\hline
\end{tabular}

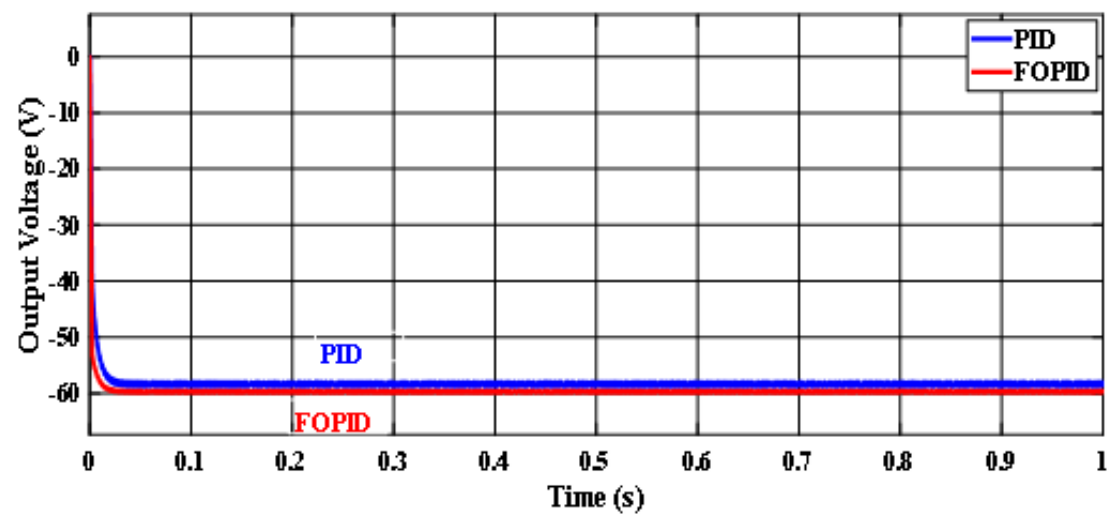

Figure 12. Comparison of output voltage of buck-boost converters using PID and FOPID controllers

\subsection{Closed loop control of DISO converters using PID and FOPID controllers}

Three PID/FOPID controllers are used to achieve the desired output voltage level by controlling the two switches in the converter. The designed values for the parameters of DISO converter is listed in the Table 10.The tuned values of the controller gains are tabulated in Table 11. The two voltage sources are used in which $V_{1}$ is the higher voltage and $V_{2}$ is the lower voltage source. The value of output voltage can be calculated using the equation 14 in section 1.4. The rise time and settling time of the converter is considerably reduced with the use of FOPID controller as given in the Table 12. The comparison of response of the DISO converter under PID and FOPID controllers are shown in Figure 13.

Table 10. Parameters of the DISO DC-DC converter

\begin{tabular}{cc}
\hline Parameter & Value \\
\hline Input Voltage $V_{1}$ & $300 \mathrm{~V}$ \\
Input Voltage $V_{2}$ & $150 \mathrm{~V}$ \\
Inductance L & $10 \mathrm{mH}$ \\
Capacitance C & $1000 \mu \mathrm{F}$ \\
Load Resistance R & $180 \Omega$ \\
Switching frequency & $5000 \mathrm{~Hz}$ \\
\hline
\end{tabular}

Table 11. Design values of controllers

\begin{tabular}{ccccccc}
\hline \multicolumn{2}{c}{ Controller } & $K_{P}$ & $K_{I}$ & $K_{D}$ & $\lambda$ & $\mu$ \\
\hline \multirow{4}{*}{ PID } & PID1 & 0.854 & 70 & 0.0012 & - & - \\
& PID2 & 0.95 & 85 & 0.0035 & - & - \\
& PID3 & 0.856 & 75 & 0.0025 & - & - \\
\multirow{4}{*}{ FOPID } & FOPID1 & 0.95 & 0.85 & 0.75 & 0.999 & 0.95 \\
& FOPID2 & 0.65 & 0.55 & 0.0214 & 0.7 & 0.9 \\
& FOPID3 & 0.45 & 0.25 & 0.0024 & 0.6 & 0.75
\end{tabular}

Table 12. The performance comparison of DISO converter with conventional PID and FOPID controllers

\begin{tabular}{cccccccccc}
\hline Controller & $V_{1}(V)$ & $V_{2}(V)$ & $V_{O}(V)$ & $\begin{array}{c}\text { Rise Time } \\
(\mathrm{ms})\end{array}$ & $\begin{array}{c}\text { Slew Rate } \\
(\mathrm{mv} / \mathrm{ms})\end{array}$ & $\begin{array}{c}\text { Ripple } \\
(\mathrm{V})\end{array}$ & $\begin{array}{c}\text { Over shoot } \\
\%\end{array}$ & $\begin{array}{c}\text { Under shoot } \\
\%\end{array}$ & $\begin{array}{c}\text { Settling Time } \\
(\mathrm{ms})\end{array}$ \\
\hline PID & 300 & 150 & 292 & 105.149 & 2.222 & 10 & 6.634 & 7.739 & 0.249 \\
FOPID & 300 & 150 & 309 & 46.578 & 5.323 & 1 & 0.948 & 3.944 & 0.022 \\
\hline
\end{tabular}




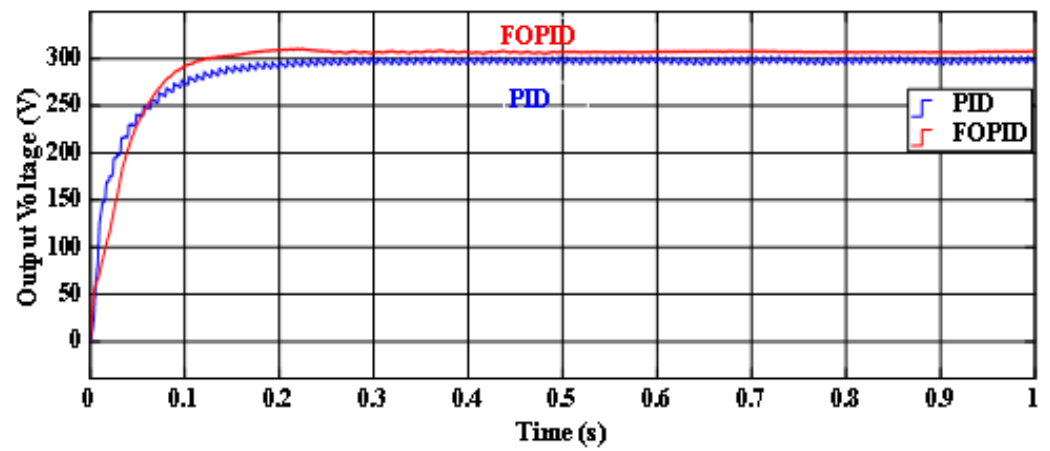

Figure 13. Comparison of output voltage of DISO converters using PID and FOPID controllers

\section{CONCLUSION}

The closed loop control of buck, boost, buck-boost and DISO converters are carried out with conventional PID controller and Fractional Order PID controller. The performance were evaluated in terms of various time domain specifications such as rise time, settling time, output voltage ripple, overshoot, undershoot etc. For all types of converters, the performance of FOPID controller gave far better result as compared with conventional PID controllers. The ripple content of the output voltage is reduced to an appreciable lower value and almost constant voltage can be observed across the load with the use of FOPID controllers. Hence, these converters with FOPID controllers can be used in the applications such as grid connected/isolated PV or wind or hybrid renewable generating systems to regulate the DC bus voltage under variable irradiance, variable temperature, variable wind etc. It is mandatory to regulate the DC bus voltage for maximum power extraction. Hence the studies and analysis conducted in the paper is more relevant. The performance of FOPID controller can be further improved by introducing some optimization techniques to tune the gain parameters more precisely.

\section{REFERENCES}

[1] S. Mariethoz et al., "Comparison of Hybrid Control Techniques for Buck and Boost DC-DC Converters," in IEEE Transactions on Control Systems Technology, vol. 18, no. 5, pp. 1126-1145, Sept. 2010

[2] Rubaai, A. R. Ofoli, L. Burge and M. Garuba, "Hardware implementation of an adaptive network-based fuzzy controller for DC-DC converters," in IEEE Transactions on Industry Applications, vol. 41, no. 6, pp. 1557-1565, Nov.-Dec. 2005

[3] B. Wang, V. R. K. Kanamarlapudi, L. Xian, X. Peng, K. T. Tan and P. L. So, "Model Predictive Voltage Control for Single-Inductor Multiple-Output DC-DC Converter With Reduced Cross Regulation," in IEEE Transactions on Industrial Electronics, vol. 63, no. 7, pp. 4187-4197, July 2016.

[4] T. Geyer, G. Papafotiou and M. Morari, "Hybrid Model Predictive Control of the Step-Down DC-DC Converter," in IEEE Transactions on Control Systems Technology, vol. 16, no. 6, pp. 1112-1124, Nov. 2008.

[5] M. Salimi and S. Siami, "Closed-Loop control of DC-DC buck converters based on exact feedback linearization," 2015 4th International Conference on Electric Power and Energy Conversion Systems (EPECS), Sharjah, pp. 1-4, 2015.

[6] Mohan, N., Undeland, T. M., \& Robbins, W. P. Power electronics: Converters, applications, and design. New York: Wiley, 1995.

[7] M. H. Rashid, "Power Electronics-Circuits, Devices and Applications," 3rd Edition, Pearson Education, 2003.

[8] D. Vasanthakumar and V. Srikanth, "DC-DC converter control using IP controller", in Computation of Power, Energy, Information and Communication (ICCPEIC), 2014 International Conference on, 2014

[9] I. Podlubny. Fractional-order systems and $P I^{\lambda} D^{\mu}$-controllers. IEEE Transactions on Automatic Control, vol. 44, no. 1, pp. 208-214, 1999.

[10] K. Gopinathan and Mamatha, I., "Average current mode controlled DC-DC converter using digital controllers", in Power and Energy Systems: Towards Sustainable Energy (PESTSE), 2016 Biennial International Conference on, 2016.

[11] Cheng-Ching Yu. Auto tuning of PID Controllers: Relay Feedback Approach. Advances in Industrial Control. Springer-Verlag, London, 1999

[12] T. Deepti, Dr. K. Deepa, and M Kumar, V., "Design and implementation of 30W DC-DC converter for Aerospace application", International Review on Modelling and Simulations (IREMOS), vol. 6, pp. 323-328, 2013.

[13] S. Mariethoz et al., "Comparison of Hybrid Control Techniques for Buck and Boost DC-DC Converters," in IEEE Transactions on Control Systems Technology, vol. 18, no. 5, pp. 1126-1145, Sept. 2010. 
[14] A. Rubaai, A. R. Ofoli, L. Burge and M. Garuba, "Hardware implementation of an adaptive network-based fuzzy controller for DC-DC converters," in IEEE Transactions on Industry Applications, vol. 41, no. 6, pp. 1557-1565, Nov.-Dec. 2005.

[15] T. Geyer, G. Papafotiou and M. Morari, "Hybrid Model Predictive Control of the Step-Down DC-DC Converter," in IEEE Transactions on Control Systems Technology, vol. 16, no. 6, pp. 1112-1124, Nov. 2008.

[16] D. Jovcic and H. Zhang, "Dual Channel Control With DC Fault Ride Through for MMC-Based, Isolated DC/DC Converter," in IEEE Transactions on Power Delivery, vol. 32, no. 3, pp. 1574-1582, June 2017.

[17] H. Behjati, A. Davoudi and F. Lewis, "Modular DC-DC Converters on Graphs: Cooperative Control," in IEEE Transactions on Power Electronics, vol. 29, no. 12, pp. 6725-6741, Dec. 2014.

[18] D. Zhu, L. Liu and C. Liu, "Optimal fractional-order PID control of chaos in the fractional-order BUCK converter," 2014 9th IEEE Conference on Industrial Electronics and Applications, Hangzhou, pp. 787-791, 2014.

[19] Z. Wu, D. Li and L. Wang, "Control of the superheated steam temperature: A comparison study between PID and fractional order PID controller," 2016 35th Chinese Control Conference (CCC), Chengdu, pp. 10521-10526, 2016.

[20] R. Gong, G. Zhang, J. Luo, Y. Yang and Y. Tian, "A new design method of fractional order PI $\lambda \mathrm{D} \mu$ controller," Proceedings of the 29th Chinese Control Conference, Beijing, pp. 194-198, 2010.

[21] H. R. Patel and V. A. Shah, "Comparative study between Fractional Order PID and Integer Order PID Controller: A case study of coupled conical tank system with actuator faults," 2019 4th Conference on Control and Fault Tolerant Systems (SysTol), Casablanca, Morocco, pp. 390-396, 2019.

[22] P. Varshney and S. K. Gupta, "Implementation of fractional Fuzzy PID controllers for control of fractional-order systems," 2014 International Conference on Advances in Computing, Communications and Informatics (ICACCI), New Delhi, pp. 1322-1328, 2014.

[23] P. K. Bhamre and C. B. Kadu, "Design of a smith predictor based fractional order PID controller for a coupled tank system," 2016 International Conference on Automatic Control and Dynamic Optimization Techniques (ICACDOT), Pune, pp. 705-708, 2016.

[24] S. Konar, M. D. Patil and V. A. Vyawahare, "Design of a Fractional Order Sliding Mode Controller for Depth Control of AUV," 2018 Second International Conference on Intelligent Computing and Control Systems (ICICCS), Madurai, India, pp. 1342-1345, 2018.

[25] K. Qian, H. Xiong and D. Lei, "Design of PWM Rectifier Based on Fractional Order PID Control," 2017 International Conference on Industrial Informatics - Computing Technology, Intelligent Technology, Industrial Information Integration (ICIICII), Wuhan, pp. 215-218, 2017.

\section{BIOGRAPHIES OF AUTHORS}

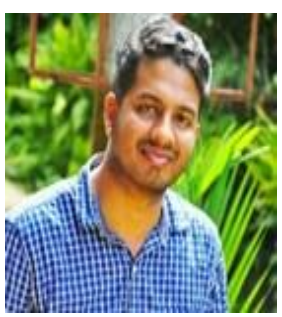

Aseem K: Received his B.Tech degree in Electrical and Electronics Engineering from Kannur University in 2007 and M.Tech degree in Power Systems Engineering from University of Calicut in 2010.He joined the Department of Electrical and Electronics Engineering, LBS College of Engineering, Kasaragod, Kerala as Assistant Professor in 2012. He is currently pursuing the Ph.D. degree at the Department of Electrical and Electronics Engineering, Amrita School of Engineering, Amrita Vishwa Vidyapeetham, Coimbatore.His field of interest includes Control Systems, Hybrid Energy Systems, Power Electronics and Power Quality. He is a Life Member of the Indian Society for Technical Education (ISTE) and Member of Institution of Electrical and Electronics Engineers (IEEE).

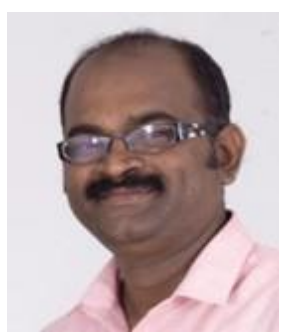

Dr. S. Selva Kumar currently serves as Assistant Professor (SG) at the Department of Electrical and Electronics Engineering at Amrita School of Engineering, Amrita VishwaVidyapeetham, Coimbatore, Tamil Nadu. He joined Amrita in the year 2008 before which he was working as a lecturer in VLB Janakiammal College of Engineering and Technology, Coimbatore. He obtained his Bachelor's degree in Electrical and Electronics Engineering from Sri Ramakrishna Engineering College, Bharathiyar University, Coimbatore in 2001 and Master's degree in Process Control and Instrumentation from Annamalai University, Chidambaram, Tamil Nadu in 2005. He obtained his Ph.D. from Anna University, Chennai in the year 2016. His Research interests are Instrumentation, Control systems, Process Control, Electrical Machines, Power Systems Operation and Control. 